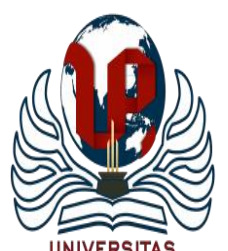

Jurnal Basicedu Volume 4 Nomor 4 Tahun 2020 Halaman 1236 - 1245

JURNAL BASICEDU

Research \& Learning in Elementary Education

https://jbasic.org/index.php/basicedu

\title{
Pengembangan Perangkat Pembelajaran Matematika Berbasis Kompetensi 4K Anies Baswedan dan Multiple Intelligences
}

\author{
Afib Rulyansah ${ }^{1}$, Ludfi Arya Wardana ${ }^{2}$ \\ Pendidikan Guru Sekolah Dasar, , Universitas Panca Marga, Jawa Timur, Indonesia ${ }^{1,2}$ \\ E-mail: afibrulyansah@upm.ac.id ${ }^{1}$ ludfiaryawardana@upm.ac.id ${ }^{2}$
}

\begin{abstract}
Abstrak
Keterampilan-keterampilan yang harus dimiliki oleh peserta didik juga memerlukan kecerdasan yang sesuai dengan kompetensi yang dimiliki, terutama pada pembelajaran matematika sering kali tidak disukai siswa. Pengembangan perangkat pembelajaran perlu dilakukan agar dapat menghasilkan perangkat pembelajaran matematika yang valid, praktis, menarik dan efektif. Jenis penelitian yang dilakukan adalah penelitian dan pengembangan atau yang sering disebut Research and Development (R\&D). Model pengembangan pada penelitian ini diadaptasi dari ADDIE yang berbasis pada Multiple Intelligences dan Kompetensi 4K Anies Baswedan. Berdasarkan hasil penilaian validasi dari ahli desain pembelajaran menunjukkan rata-rata 4,8 dengan presentase 96\%. Ahli materi dan LKS menunjukkan rata-rata 5 dengan presentase $100 \%$. Hasil ahli perangkat pembelajaran matematika kelas V yang didapat menunjukkan nilai rata-rata 4,7 dengan persentase 95\%. Respon siswa terhadap learning media matematika berbasis kompetensi 4K Anies Baswedan dan Multiple Intelligence yang dikembangkan menunjukkan hasil persentase ratarata diatas $85 \%$ yang berarti sebagian besar siswa memberikan respon positif atau sangat kuat. Berdasarkan temuan hasil penelitian dapat dikatakan bahwa perangkat pembelajaran matematika berbasis kompetensi $4 \mathrm{~K}$ Anies Baswedan dan Multiple Intelligence sangat praktis, efektif dan menarik dalam proses belajar dikelas dengan persentase $98 \%$.
\end{abstract}

Kata kunci: perangkat pembelajaran matematika, kompetensi $4 \mathrm{~K}$ anies baswedan, multiple intelligence

\begin{abstract}
The skills that must be possessed by students also require intelligence that is in accordance with their competencies, especially in learning mathematics, which is often not liked by students. The development of learning tools needs to be done in order to produce valid, practical, interesting and effective mathematics learning tools. This type of research is research and development or what is often called Research and Development $(R \& D)$. The development model in this study was adapted from ADDIE based on Anies Baswedan's Multiple Intelligences and $4 K$ Competencies. Based on the results of the validation assessment from the learning design expert, it shows an average of 4.8 with a percentage of $96 \%$. Material experts and worksheets show an average of 5 with a percentage of $100 \%$. The results obtained by the expert of class $V$ mathematics learning devices showed an average value of 4.7 with a percentage of 95\%. Student responses to Anies Baswedan's 4 K competency-based mathematics learning media and the Multiple Intelligence developed showed an average percentage result of above $85 \%$, which means that most students gave a positive or very strong response. Based on the findings of the research, it can be said that Anies Baswedan's 4 K competency-based mathematics learning device and Multiple Intelligence are very practical, effective and interesting in the learning process in the classroom with a percentage of $98 \%$.
\end{abstract}

Keywords: mathematics learning tools, anies baswedan's 4 K competence, multiple intelligence

Copyright (c) 2020 Afib Rulyansah, Ludfi Arya Wardana

$\checkmark$ Corresponding author

Address : Universitas Panca Marga

Email : afibrulyansah@upm.ac.id

Phone : 085236868125

DOI: https://doi.org/10.31004/basicedu.v4i4.539
ISSN 2580-3735 (Media Cetak)

ISSN 2580-1147 (Media Online) 
1237 Pengembangan Perangkat Pembelajaran Matematika Berbasis Kompetensi 4K Anies Baswedan dan Multiple Intelligences - Afib Rulyansah, Ludfi Arya Wardana

DOI: https://doi.org/10.31004/basicedu.v4i4.539

\section{PENDAHULUAN}

Pekembangan zaman yang pesat memberi dampak signifikan bagi bidang pendidikan. Perkembangan ini juga memberikan beberapa tantangan dan tuntutan bagi sumber daya manusia. Hal ini juga perlu diperhatikan oleh para lembaga pendidikan, yang bertugas memberikan proses pembelajaran mendasar hingga menengah harus memberi dampak positif yang sesuai dengan kebutuhan di masa yang depan. Zaman yang semakin berkembang dan maju memerlukan output pendidikan yang memiliki kompetensi kritis, kreatif, komunikatif, dan kolaboratif yang telah dikemukakan oleh Anies Baswedan. (Fadhilah, 2016).

Keterampilan-keterampilan yang harus dimiliki oleh peserta didik juga memerlukan kecerdasan yang sesuai dengan kompetensi yang dimilikinya. Masing-masing manusia memiliki karakter kecerdasan pada bidang tertentu. Dalam menghadapi perkembangan zaman dan menuju pada era baru. Peserta didik diharapkan dapat memiliki kemampuan berpikir sesuai dengan karakter kecerdasan yang dimilikinya, sesuai dengan kemampuan bidang berpikirnya, dan kompetensi yang memadai. Idealnya dasar gagasan diwujudkan dalam kegiatan pembelajaran berdasarkan kompetensi yang diperlukan saat ini. Dalam pencapaian tersebut peserta didik memerlukan tata cara pembelajaran yang lebih baik, model, strategi dan tingkat pemahaman peserta didik pada pembelajaran yang dilakukan, pemodelan dan pengorganisasian yang tepat untuk peserta didik. (Rulyansah et al., 2018).
Pemberian proses pembelajaran yang sesuai dengan peserta didik memerlukan peran penting tenaga pendidik. Dalam hal ini tenaga pendidik masih mengalami beberapa kesulitan. Hal yang tersulit adalah ketika memberi kegiatan belajar mengenai mata pelajaran matematika. Matematika adalah salah satu jenis mata pelajaran yang menjadi musuh banyak peserta didik dan sedikit peminat. Kesulitan yang dialami peserta didik, yakni dalam materi pembelajaran seperti, Kelipatan Persekutuan Kecil (KPK) dan Faktor Persekutuan Terbesar (FPB) (Sugiyarti, dkk 2018).

Pembelajaran yang diterapkan saat ini tidak dapat memberikan gambaran tentang karakter kecerdasan peserta didik, sehingga proses perkembangan belajar peserta didik rendah. Penyusunan learning media yang belum dikuasai secara penuh oleh tenaga pendidik memberikan kendala besar dalam penerapan kegiatan belajar. Penyusunan learning media yang terdiri dari silabus, Rencana Pelaksanaan Pembelajaran (RPP), dan soal evaluasi membuat tenaga pendidik sering kali kewalahan. Hal ini berakibat pada tidak sesuainya learning media yang disusun dengan karakter peserta didik, kurangnya cangkupan materi, penggunaan media yang tidak sesuai, dan penguasaan kompetensi peserta didik rendah. Penerapan pembelajaran tidak sesuai dengan tujuan dari kurikulum 2013.

Suci \& Taufina (2020) berpendapat setiap permasalahan yang muncul dalam kehidupan keseharian, dapat diselesaikan salah satunya dengan ilmu yang ada dalam matematika. Oleh karena itu, pembelajaran matematika di sekolah perlu dirancang secara ideal. Menurut Sugiyarti et 
1238 Pengembangan Perangkat Pembelajaran Matematika Berbasis Kompetensi 4K Anies Baswedan dan Multiple Intelligences - Afib Rulyansah, Ludfi Arya Wardana

DOI: https://doi.org/10.31004/basicedu.v4i4.539

al. (2018) untuk mencapai kualitas pengajaran yang tinggi, setiap mata pelajaran harus diorganisasikan dengan model pengorganisasian yang tepat dan selanjutnya disampaikan kepada peserta didik dengan model yang tepat pula.

Seperti halnya yang dikemukakan oleh Rafianti et al. (2018) dalam penelitian Pengembangan Learning media Matematika dalam Mendukung Kemampuan Abad 21 (Kompetensi Kritis, Kreatif, Kolaboratif, dan Komunikatif) bahwa berdasarkan keseluruhan skor dalam penelitian yang telah diperoleh dari proses pengujian menunjukkan bahwa learning media matematika ini sangat bagus dengan adanya pembuatan produk learning media berbasis kompetensi 4K. Perkembangan learning media berbasis $4 \mathrm{~K}$ Anies Baswedan dan Multiple Intelligence dapat memberikan topik pembelajaran yang baru terutama pada proses pembelajaran matematika materi Kelipatan Persekutuan Kecil (KPK) dan Faktor Pesekutuan Besar (FPB) sesuai dengan perkembangan kurikulum. Seperti yang di kemukakan oleh Kartikasari \& Widjajanti (2015) dalam penelitiannya berjudul Pengembangan Learning media Matematika Berbasis Howard Gardner's Multiple Intelligences Berorientasi pada Kemampuan Koneksi Matematis Siswa Kelas VIII SMP bahwa tingkat kepraktisan learning media dengan berbasis Multiple Intelligence memberikan kepraktisan yang sangat baik sehingga efektif ketika digunakan dalam proses pembelajaran. Pernyataan tersebut diperkuat oleh penelitian yang dilakukan Laksmiwati \& Retnowati (2019) berjudul Pengembangan Learning Media Geometri Berbasis Kecerdasan Majemuk Siswa SMP Kelas
VIII bahwa pengembangan kualitas learning media mata pelajaran matematika berbasis kecerdasan majemuk dapat menghasilakan efisiensi learning media yang efektif. Kecerdasan majemuk ini telah ada dalam diri peserta didik sejak mereka dilahirkan, hanya saja cara untuk mengetahui dan memahami hal tersebut memerlukan beberapa cara yang harus dilakukan oleh tenaga pendidik.

Berdasarkan hasil dari studi kasus yang dilakukan selama sepuluh (10) hari, dimulai dari tanggal 1-10 Februari 2020 melalui pengumpulan data dengan wawancara pada beberapa tenaga pengajar dan peserta didik terdekat diperoleh beberapa masalah. Permasalahan tersebut diantaranya, 1) pembuatan learning media matematika yang masih menggunakan cara sederhana dan tidak sepenuhnya sesuai dengan karakter peserta didik (karakter kecerdasanMultiple Intellegence), 2) cangkupan materi dan soal-soal pembelajaran matematika yang masih pada taraf rendah, tidak mencakup semua konsep dasar, 3) kurangnya proses pembelajaran yang menerapkan kompetensi 4K Anies Baswedan, 4) penggunaan media, model, dan stategi pembelajaran yang masih konvensional dan tidak sepenuhnya sesuai dengan kurikulum 2013 dan karakter kecerdasan anak, 5) peserta didik mengalami kesulitan dalam pembelajaran matematika materi KPK dan FPB, 6) proses pembelajaran yang tidak merangsang kemampuan berpikir ganda peserta didik. Hal tersebut dapat berpengaruh dalam hasil belajar dan pembuatan learning media matematika. 
1239 Pengembangan Perangkat Pembelajaran Matematika Berbasis Kompetensi 4K Anies Baswedan dan Multiple Intelligences - Afib Rulyansah, Ludfi Arya Wardana

DOI: https://doi.org/10.31004/basicedu.v4i4.539

Berdasarkan permasalahan yang ada, peneliti memilih pemecahan masalah dengan melakukan pengembangan learning media matematika berbasis kompetensi $4 \mathrm{~K}$ Anies Baswedan dan Multiple Intelligence. Learning media matematika ini terdiri dari Rencana Pelaksanaan Pembelajaran (RPP), Lembar Kegiatan Siswa (LKS), dan Soal Evaluasi. Dari isi learning media, tenaga pengajar dapat memberikan proses pembelajaran dengan metode pembelajaran berbasis kompetensi $4 \mathrm{~K}$ Anies Baswedan dan strategi pembelajaran berbasisi Multiple Intelligence. Pembuatan soal dalam Lembar Kegiatan Siswa (LKS) maupun soal evaluasi dapat dilakukan dengan jenis soal yang sesuai dengan kecerdasan peserta didik berbasis Multiple Intelligence.

\section{METODE}

Jenis penelitian yang dilakukan adalah penelitian dan pengembangan atau yang sering disebut Research and Development (R\&D). Menurut Purnomo (2016) metode penelitian dan pengembangan atau Research and Development (R\&D) adalah suatu metode penelitian yang digunakan untuk menghasilkan produk tertentu dan menguji tingkat efektifitasnya. Menurut Borg \& Gall (dalam Rayanto \& Sugianti, 2020) model penelitian dan pengembangan adalah "a process used developand validate educational product". Artinya penelitian dan pengembangan adalah usaha dalam mengembangkan dan validasi produkproduk yang digunakan dalam proses pembelajaran. Model pengembangan pada penelitian ini diadaptasi dari ADDIE yang berbasis pada Multiple Intelligences dan Kompetensi 4K Anies Baswedan. Model ADDIE (Analysis, Design, Develop, Implement, Evaluate) yang muncul pada tahun 1996 yang dikembangkan oleh Dick and Carry. Model ini menggunakan 5 tahap pengembangan dengan langkah-langkah pada gambar berikut.

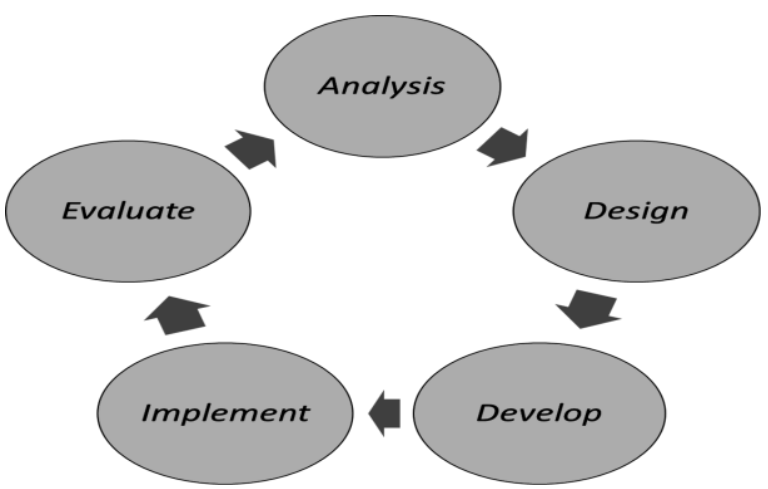

Gambar 1. Langkah-Langkah Penelitian dan Pengembangan Model ADDIE (Rayanto \& Sugianti, 2020)

Adapun yang diposisikan sebagai fokus lokasi pengembangan adalah SD Islah Fatahillah, Sumberkerang, Gending, Probolinggo. SDI Fatahillah dipilih sebagai fokus tempat pengembangan learning media matematika dengan alasan hasil dari wawancara bersama beberapa tenaga pendidik dan peserta didik terdekat, sekolah ini memiliki dominan permasalahan pada proses manajemen learning media sekolah. Menurut Rulyansah et al. (2018) Hasil temuan riset diwujudkan dalam simpulan kemudian dilakukan pengecekan kevalidan dengan maksud hasil data simpulan memiliki level kevalidan (kereliabilitasan) yang memadai (baik) sehingga simpulan data yang disebutkan itu bisa dipertanggungjawabkan. Teknik (cara) yang dimanfaatkan untuk menguji (memverifikasi) kevalidan (kereliabilitasan) data dalam pengkajian 
1240 Pengembangan Perangkat Pembelajaran Matematika Berbasis Kompetensi 4K Anies Baswedan dan Multiple Intelligences - Afib Rulyansah, Ludfi Arya Wardana

DOI: https://doi.org/10.31004/basicedu.v4i4.539

ini adalah uji coba produk melalui kelompok eksperimen dan kelompok kontrol. Teknik pengumpulan data untuk penelitian ini adalah observasi, angket respon siswa, angket validasi ahli media dan ahli materi serta ahli learning media. Instrumen yang digunakan dalam penelitian ini adalah sebagai berikut: 1) instrumen kelayakan perangkat pembelajaran, 2) instrumen Kepraktisan dan kemenarikan perangkat pembelajaran matematika, dan 3) instrumen Keefektifan perangkat pembelajaran matematika. (Firdaus et al., 2020)

\section{HASIL DAN PEMBAHASAN}

Penelitian ini dilaksanakan dengan tujuan mengembangkan perangkat pembelajaran matematika berbasis kompetensi $4 \mathrm{~K}$ Anies Baswedan dan Multiple Intelligence yang valid, praktis, menarik dan efektif.

\section{Kelayakan Learning Media}

Tabel 1. Hasil Rekapitulasi Validasi Desain Pembelajaran Matematika

\begin{tabular}{|c|c|c|}
\hline $\begin{array}{c}\text { Rata-rata } \\
\text { penilaian }\end{array}$ & $\begin{array}{c}\text { Persetage of } \\
\text { Agreement }\end{array}$ & Kategori \\
\hline 4,8 & $96 \%$ & Sangat Valid \\
\hline
\end{tabular}

Berdasarkan hasil penilaian dari ahli desain pembelajaran menunjukkan rata-rata 4,8 dengan presentase $96 \%$. Dari hasil penilaian yang diberikan oleh ahli desain pembelajaran dapat dikatakan perangkat pembelajaran yang telah dibuat peneliti sangat layak untuk digunakan sebagai perangkat pembelajaran.

Tabel 2. Hasil Rekapitulasi Validasi Materi dan LKS

\begin{tabular}{|c|c|c|}
\hline $\begin{array}{c}\text { Rata-rata } \\
\text { penilaian }\end{array}$ & $\begin{array}{c}\text { Persetage of } \\
\text { Agreement }\end{array}$ & Kategori \\
\hline 5 & $100 \%$ & Sangat Valid \\
\hline
\end{tabular}

Berdasarkan hasil penilaian dari ahli materi dan LKS menunjukkan rata-rata 5 dengan presentase $100 \%$. Dalam penilaian yang telah diberikan oleh validator menyatakan bahwa perangkat pembelajaran yang dibuat telah layak untuk digunakan karena memenuhi syarat dari hal kemenarikan, kepraktisan, dan mudah untuk digunakan, serta dapat memotivasi siswa dalam pembelajaran.

\section{Kepraktisan dan Kemenarikan Perangkat Pembelajaran Matematika Kelas V Berbasis Kompetensi 4K Anies Baswedan dan Multiple Intelligence}

Keperaktisan dan kemenarikan perangkat pembelajaran matematika kelas $\mathrm{V}$ berbasis kompetensi 4K Anies Baswedan dan Multiple Intelligence dapat dilihat dari keterlaksanaan RPP dan LKS yang diawasi oleh dua orang pengamat.

\section{Keterlaksanaan RPP dan LKS}

Hasil pengamatan keterlaksanaan kegiatan pembelajaran menggunakan perangkat pembelajaran matematika berbasis kompetensi 4K Anies Baswedan dan Multiple Intelligence yang telah dilakukan analisis pada proses pelaksanaan pembelajaran baru.

Tabel 3. Hasil Rekapitulasi Keterlaksanaan RPP dan LKS

\begin{tabular}{|c|c|c|}
\hline $\begin{array}{c}\text { Rata-rata } \\
\text { penilaian }\end{array}$ & $\begin{array}{c}\text { Persetage of } \\
\text { Agreement }\end{array}$ & Kategori \\
\hline 4,7 & $95 \%$ & Sangat Baik \\
\hline
\end{tabular}

Berdasarkan hasil penilaian ahli perangkat pembelajaran matematika kelas $\mathrm{V}$ yang 
1241 Pengembangan Perangkat Pembelajaran Matematika Berbasis Kompetensi 4K Anies Baswedan dan Multiple Intelligences - Afib Rulyansah, Ludfi Arya Wardana

DOI: https://doi.org/10.31004/basicedu.v4i4.539

didapat menunjukkan nilai rata-rata 4,7 dari aspek kepraktisan dan kemenarikan RPP serta LKS. Hasil persentase nilai yang didapat yakni 95\% tanpa ada kritik atau komentar apapun, yang artinya perangkat pembelajaran yang telah dibuat oleh peneliti layak untuk digunakan, menarik, memotivasi, praktis, dan efektif dalam pelaksanaan.

2. Hasil Analisis Aktivitas Belajar Siswa

Aktivitas siswa dalam proses pembelajaran diamati oleh dua orang pengamat. Pengamatan dilakukan selama proses pembelajaran berlangsung, dari awal sampai akhir pembelajaran. Jenis aktivitas siswa yang diamati oleh pengamat sebanyak 15 (lima belas) dalam kelas eksperimen dengan pembelajaran baru. Proses pembelajaran yang dilakukan menggunakan dua kelompok belajar, yakni kelompok eksperimen dan kelompok kontrol. Pada kelompok kontrol terdapat 8 orang dengan proses pembelajaran secara konvensional.

Pembagian siswa ini diambil dari hasil rekapitulasi angket Multiple Intelligence yang diberikan kepada siswa sebelumnnya. Kelompok eksperimen adalah kelompok yang dipilih sebagai kelompok yang diberikan treatment sesuai dengan pengembangan yang akan dilakukan. Dalam hal ini karakter kecerdasan yang dominan di dalam kelas adalah 3 kecerdasan yang memiliki tingkatan teratas yakni kecerdasan verbal-lnguistik, kecerdasan logika-matematika, dan kecerdasan visual spatial dengan rata-rata 0,9-1 dari angket yang diberikan.
Dalam pengukuran kompetensi, kolaboratif dan komunikatif, dilakukan dengan observasi siswa selama proses pembelajaran, hasil pengamatan yang diperoleh kelompok eksperimen mendapatkan presentase nilai ratarata 98\%, sedangkan pada kelompok kontrol mendapatkan $87,5 \%$. Hal ini memberikan hasil bahwa dengan penggunaan perangkat pembelajaran matematika berbasis kompetensi 4K Anies Baswedan dan Multiple Intelligence memberikan peningkatan penguasaan kompetensi kolaboratif dan komunikatif siswa.

\section{Keefektifan Perangkat Pembelajaran \\ Matematika Berbasis Kompetensi 4K Anies Baswedan dan Multiple Intelligence}

1. Respon Siswa

Angket respon siswa diberikan pada siswa setelah uji akhir. Secara umum respon siswa terhadap learning media matematika berbasis kompetensi 4K Anies Baswedan dan Multiple Intelligence yang dikembangkan menunjukkan hasil persentase rata-rata diatas $85 \%$ yang berarti sebagian besar siswa memberikan respon positif atau sangat kuat sedangkan sisanya merupakan respon kurang senang dan menarik terhadap pembelajaran yang dilakukan.

2. Hasil Tes Kompetensi Kritis dan Kreatif Soal yang diujicobakan pada 15 orang siswa kelas V SD Fatahillah untuk mengetahui tingkat validitas dan reliabilitas, daya pembeda, serta indeks kesukaran butir soal. Pada penelitian ini ujivaliditas dilakukan untuk mengukur tingkat kesahian dan kelayakan soal 
1242 Pengembangan Perangkat Pembelajaran Matematika Berbasis Kompetensi 4K Anies Baswedan dan Multiple Intelligences - Afib Rulyansah, Ludfi Arya Wardana

DOI: https://doi.org/10.31004/basicedu.v4i4.539

untuk digunakan. Hal ini diolah menggunakan kolerasi product moment dengan bantuan SPSS versi 21. Pada aktivitas pembelajaran yang dilakukan, pengukuran kompetensi kritis dan kreatif yang disesuaikan karakter kecerdasan siswa dilakukan dengan tes, jenis soal uraian open-ended question dan game open-ended question yang diberikan untuk kelas eksperimen. Aktivitas berpikir kritis dan kreatif siswa mendapatkan presentase nilai rata-rata $77,6 \%$ sesuai dengan perolehan nilai jawaban siswa, sedangkan kelompok kontrol mendapatkan presentase nilai rata-rata $68,7 \%$.

Tabel 4. Hasil Uji Validitas dan Reliabilitas Soal Evaluasi

\begin{tabular}{|c|c|c|c|}
\hline & $\mathrm{r}_{\text {hitung }}$ & $\mathrm{r}_{\text {tabel }}$ & Keterangan \\
\hline A.1 & 0,62 & 0,51 & Valid \\
\hline A.2 & 0,72 & 0,51 & Valid \\
\hline A.3 & 0,58 & 0,51 & Valid \\
\hline A.4 & 0,53 & 0,51 & Valid \\
\hline A.5 & 0,61 & 0,51 & Valid \\
\hline
\end{tabular}

Setelah dilakukan validitas, 5 soal yang akan diujikan telah valid, selanjutnya adalah pengujian reliabilitas menggunakan korelasi Alfa Chronbach's diolah menggunakan bantuan software SPSS Version 21. Hasil uji reliabilitas butir soal menunjukkan nilai relibel sebesar 0,56 > 0,40 sehingga kriteria reliabilitasnya sedang dan sudah dapat dikatakan reliabel.

Tebel 5. Hasil Uji Daya Pembeda Soal Evaluasi

\begin{tabular}{|l|c|c|c|c|c|}
\hline & $\sum \bar{X}$ & $\bar{X} \mathrm{~A}$ & $\bar{X} \mathrm{~B}$ & $\mathrm{DP}$ & Kriteria \\
\hline A.1 & 54 & 4,14 & 3,00 & 0,23 & Sedang \\
\hline A.2 & 49 & 3,86 & 2,71 & 0,23 & Sedang \\
\hline A.3 & 56 & 4,29 & 3,14 & 0,23 & Sedang \\
\hline A.4 & 54 & 4,29 & 3,00 & 0,26 & Sedang \\
\hline A.5 & 51 & 4,29 & 2,57 & 0,34 & Sedang \\
\hline
\end{tabular}

Daya pembeda sebuah soal menyatakan bahwa seberapa jauh kemapuan butir soal tersebut dapat membedakan anatara hasil testi yang mengetahui jawaban dengan benar dan testi yang tidak dapat menjawab soal tersebut (menjawab salah). Berdasarkan tabel 5 menunjukkan bahwa soal evaluasi yang akan telah diujikan memiliki tingakt pembeda soal dengan kriteria sedang.

Tabel 6. Hasil Uji Indeks Kesukaran Soal Evaluasi

\begin{tabular}{|c|c|c|c|c|}
\hline & $\bar{X}$ & SM & TK & Kriteria \\
\hline A.1 & 3,47 & 5 & 0,69 & Sedang \\
\hline A.2 & 3,40 & 5 & 0,68 & Sedang \\
\hline A.3 & 3,33 & 5 & 0,67 & Sedang \\
\hline A.4 & 2,40 & 5 & 0,48 & Sedang \\
\hline A.5 & 1,47 & 5 & 0,29 & Sukar \\
\hline
\end{tabular}

Dari tabel 6 dapat dilihat bahwa soal evaluasi nomor 1-4 memiliki kriteria kesukaran "sedang" dengan nilai tingkat kesukaran dimulai dari soal nomor 1 tingkat kesukaran 0,69 , soal nomor 2 tingkat kesukasan 0,68 , soal nomor 3 tingkat kesukaran 0,67 , dan soal nomor 4 dengan tingkat kesukaran 0,48. Tingkat kesukaran yang paling tinggi adalah soal nomor 5 yakni kriteria "sukar" dengan tingkat kesukaran 0,29. Jadi, dapat dikatakan bahwa soal evaluasi yang telah dibuat dapat digunakan dan layak.

\section{Hasil Evaluasi Penerapan Perangkat Pembelajaran Matematika Berbasisi Kompetensi 4K Anies Baswedan dan Multiple Intelligence}

Komponen perangkat pembelajaran matematika yang dibuat oleh peneliti pada penelitian ini adalah Rencana Pelaksanaan Pembelajaran (RPP), Lembar Kegiatan Siswa (LKS), dan Soal Evaluasi. Penerapan perangkat 
1243 Pengembangan Perangkat Pembelajaran Matematika Berbasis Kompetensi 4K Anies Baswedan dan Multiple Intelligences - Afib Rulyansah, Ludfi Arya Wardana

DOI: https://doi.org/10.31004/basicedu.v4i4.539

pembelajaran ini dilakukan dengan proses pembelajaran yang menggunakan model pembelajaran Problem Based Learning (PBL). Lembar Kegiatan Siswa yang sesuai dengan kecerdasan yang dimiliki dan soal evaluasi dengan penghitungan daya pembeda, reliabilitas, validasi, dan indeks kesukaran berdasarkan kecerdasan siswa. Penggunaan perangkat pembelajaran matematika berbasis Multiple Intelligence dan Kompetensi 4K Anies Baswedan memberikan tingkat kevalidan perangkat pembelajaran matematika kelas V sebesar 95\%. Dalam hal ini terdapat kategori yang didapatkan dalam keprakisan dan kemenarikan perangkat pembelajaran telah praktis dan menarik untuk digunakan, oleh sebab itu sangat baik dibrikan kepada siswa. Hal ini sesuai dengan yang dikemukakan oleh Rafianti et al. (2018) dalam penelitiannya yang berjudul Pengembangan Perangkat Pembelajaran Matematika dalam Mendukung Kemampuan Abad 21 (Kompetensi Kritis, Kreatif, Kolaboratif, dan Komunikatif) bahwa berdasarkan semua skor dalam penelitian yang telah dilakukan dari proses pengujian menunjukkan bahwa perangkat pembelajaran matematika berbasis kompetensi $4 \mathrm{~K}$ sangat bagus dalam pembelajaran.

Pembelajaran yang diberikan kepada siswa memberikan proses pembelajaran yang sesuai dengan kebutuhan siswa, hal ini sesuai dengan hasil validasi desain pembelajaran sebesar $96 \%$. Pembelajaran berbasis 4K Anies Baswedan dapat memberikan proses pembelajaran yang menyenangkan sehingga dapat memberikan pengembangan pada tingkat pemikiran kritis, kreatif, kolaboratif, dan komuniaktif. Perkembangan perangkat pembelajaran berbasis 4K Anies Baswedan dan Multiple Intelligence dapat memberikan topik pembelajaran yang baru terutama pada proses pembelajaran matematika materi Kelipatan Persekutuan Kecil (KPK) dan Faktor Pesekutuan Besar (FPB) sesuai dengan perkembangan kurikulum. Seperti yang di kemukakan oleh Kartikasari \& Widjajanti (2015) dalam penelitiannya berjudul Pengembangan Perangkat Pembelajaran Matematika Berbasis Howard Gardner's Multiple Intelligences Berorientasi pada Kemampuan Koneksi Matematis Siswa Kelas VIII SMP bahwa tingkat kepraktisan perangkat pembelajaran dengan berbasis Multiple Intelligence memberikan kepraktisan yang sangat baik sehingga efektif ketika digunakan dalam proses pembelajaran.

Perangkat pembelajaran ini juga terdapat Lembar Kegiatan Siswa (LKS). Desain LKS dan isi dari LKS serta soal evaluasi telah sesuai dengan kurikulum yang ada di sekolah. Hal ini dibuktikan dengan hasil validasi sebesar 100\%. Dengan perolehan validasi yang dapat dikatakan bagus, maka dapat dilihat bahwa soal evaluasi dan LKS yang dibuat layak untuk digunakan dan diterapkan dalam pembelajaran. LKS sangat diperlukan dalam pemberian pengarahan dan untuk jalan pencapaian kompetensi dasar yang harus dipenuhi oleh siswa. Hal ini sama dengan yang dikemukakan oleh Astari (2017) bahwa LKS bermanfaat menjadi perangkat pembelajaran pendukung buku dalam pencapaian Kompetensi Dasar (KD) peserta didik. LKS diperlukan untuk memberi pengarahan kepada peserta didik dalam kegiatan pembalajaran, 
1244 Pengembangan Perangkat Pembelajaran Matematika Berbasis Kompetensi 4K Anies Baswedan dan Multiple Intelligences - Afib Rulyansah, Ludfi Arya Wardana

DOI: https://doi.org/10.31004/basicedu.v4i4.539

oleh karena itu LKS berisikan tugas-tugas dan pembentukan konsep matematika. Selain LKS perangkat pembelajaran yang seringkali digunakan adalah soal evaluasi dengan fungsi sebagai alat untuk mengukur tingkat kemampuan siswa. Seperti yang dikemukakan Wulan \& Aristia (2018) evaluasi adalah proses penilaian terhadap pertumbuhan peserta didik dalam belajar mengajar di kelas atau disekolah, dan sebagai alat pengukur kemampuan yang dimiliki suatu siswa.

$$
\text { Dalam pengembangan perangkat }
$$
pembelajaran matematika berbasis kompetensi $4 \mathrm{~K}$ Anies Baswedan dan Multiple Intelligence terdapat beberapa keterbatasan yang tidak dapat dipungkiri oleh peneliti. Keterbatasan yang ada dalam penelitian ini adalah perangkat pembelajaran ini dikembangkan hanya pada mata pelajaran matematika kelas $\mathrm{V}$ sekolah dasar pada materi KPK dan FPB pada bilangan puluhan. Namun, hal ini berarti bahwa penelitian ini memberi peluang bagi peneliti lain untuk bisa melakukan penelitian pengembangan untuk mata pelajaran lain, semua level kelas dan bisa juga pada sekolah lain.

\section{SIMPULAN}

Berdasarkan temuan hasil penelitian dapat dikatakan bahwa perangkat pembelajaran matematika berbasis kompetensi $4 \mathrm{~K}$ Anies Baswedan dan Multiple Intelligence sangat praktis, efektif dan menarik dalam proses belajar dikelas berbeda dengan terdapat perbedaan besar antara peserta didik yang peserta didik yang mendapatkan pembelajaran secara konvesional. Hal ini dapat dilihat dengan hasil obeservasi yang dilakukan kepada siswa, yakni untuk siswa dengan perangkat pembelajaran matematika berbasis kompetensi $4 \mathrm{~K}$ Anies Baswedan dan Multiple Intelligence mendapatkan hasil respon siswa persentase $98 \%$. Dalam hal ini artinya tingkat kepraktisan, kevalidan, dan kemenarikan pembelajaran yang diberikan sangat praktis, menarik, dan valid. Berbeda jauh dengan yang ada pada kelompok kontrol yakni, kelompok dengan pembelajaran secara konvensional sebesar $87,5 \%$, dengan hal ini pembelajaran secara konvensinal masih belum dikatakan sesuai denga kebutuhan untuk siswa.

\section{DAFTAR PUSTAKA}

Astari, T. (2017). Pengembangan Lembar Kerja Siswa (LKS) Berbasis Pendekatan Realistik untuk Meningkatkan Hasil Belajar Siswa SD Kelas IV. Pelangi, 150-160.

Fadhilah, U. N. (2016). Siapkan Kompetensi Anak Abad 21 tak Butuh Teknologi. https://republika.co.id/berita/oqpu0f423/siapk an-kompetensi-anak-abad-21-tak-butuhteknologi

Firdaus, F. Z., Suryanti, S., \& Azizah, U. (2020). Pengembangan Multimedia Interaktif Berbasis Pendekatan SETS Untuk Meningkatkan Kemampuan Berpikir Kritis Siswa Sekolah Dasar. Jurnal Basicedu, 4(3), 681-689.

https://doi.org/10.31004/basicedu.v4i3.417

Kartikasari, A., \& Widjajanti, D. B. (2015). Pengembangan Perangkat Pembelajaran Matematika Berbasis Howard Gardner' s Multiple Intelligences Berorientasi pada Kemampuan Koneksi Matematis Siswa Kelas VIII SMP. Seminar Nasional Matematika Dan Pendidikan Matematika UNY, 10311040.

Laksmiwati, P. A., \& Retnowati, E. (2019). Pengembangan perangkat pembelajaran geometri berbasis kecerdasan majemuk siswa SMP kelas VIII. Pythagoras: Jurnal Pendidikan Matematika, 14(1), 1-11. https://doi.org/10.21831/pg.v14i1.26591 
1245 Pengembangan Perangkat Pembelajaran Matematika Berbasis Kompetensi 4K Anies Baswedan dan Multiple Intelligences - Afib Rulyansah, Ludfi Arya Wardana

DOI: https://doi.org/10.31004/basicedu.v4i4.539

Purnomo, S. (2016). Metode Penelitian dan Pengembangan (Pengenalan untuk Mengembangkan Produk Pembelajaran Bahasa Arab). Literasi, 19-32.

Rafianti, I., Anriani, N., \& Iskandar, K. (2018). Pengembangan Perangkat Pembelajaran Matematika dengan Pendekatan Saintifik. KALAMATIKA Jurnal Pendidikan Matematika, 3(1), 123-138.

Rayanto, Y. H., \& Sugianti. (2020). Penelitian Pengembangan Model ADDIE dan R2D2: Teori dan Praktek. Lembaga Academic \& Research Institute.

Rulyansah, A., Wardana, L. A., \& Sari, I. N. (2018). Idealisasi Ideologi Pancasila untuk Pencegahan Radikalisme melalui Aktivitas Bela Negara pada PK2MABA Universitas Panca Marga. Jurnal Pendidikan: Teori, Penelitian, Dan Pengembangan, 3(12), 1680-1687.

https://doi.org/10.17977/JPTPP.V3I12.13103

Suci, D. W., \& Taufina, T. (2020). Peningkatan Pembelajaran Matematika Melalui Strategi Berbasis Masalah di Sekolah Dasar. Jurnal Basicedu, 4(2), 505-512. https://doi.org/10.31004/basicedu.v4i2.371

Sugiyarti, L., Arif, A., \& Mursalin. (2018). Pembelajaran Abad 21 di SD. Prosiding Seminar Dan Diskusi Nasional Pendidikan Dasar, 439-444.

Wulan, A., \& Aristia, R. (2018). Jenis-Jenis Intrumen dalam Evaluasi Pembelajaran. Pendidikan, 1-13. 